\title{
Comparison on taste threshold between adult male white cigarette and clove cigarette smokers using Murphy clinical test method
}

\author{
Ronald Reyses Tapilatu, Edeh Roletta Haroen, Rosy Wihardja \\ Department of Oral Biology Faculty of Dentistry Universitas Padjadjaran
}

\begin{abstract}
The habit of smoking white cigarettes and clove cigarettes may affect the gustatory function, that is, it will cause damage to taste buds, resulting in increase in gustatory threshold. This research used the descriptive comparative method and had the purpose of obtaining an illustration of gustatory threshold and compare gustatory threshold in white cigarette smokers and clove cigarette smokers in young, male adults. For gustatory threshold evaluation the Murphy method was used to obtain a value for perception threshold and taste identification threshold using sucrose solution of $0.0006 \mathrm{M}-0.06 \mathrm{M}$ concentration. Research results indicate that the perception threshold and identification threshold of young, male adult smokers are $0.0119 \mathrm{M}$ and $0.0292 \mathrm{M}$. Young, male adult clove cigarette smokers have a perception threshold and identification threshold of $0.0151 \mathrm{M}$ and $0.0348 \mathrm{M}$. The conclusion of this research is that the perception threshold of young, male adult white cigarette smokers and clove cigarette smokers are the same, whereas the identification threshold of young, male adult white cigarette smokers and clove cigarette smokers are different, that is, the identification threshold of clove cigarette smokers is higher than that of white cigarette smokers.
\end{abstract}

Key words: White cigarette smokers, clove cigarette smokers, gustatory threshold, Murphy method

\section{INTRODUCTION}

Recently, it has been estimated that there are 1.26 billion smokers in the world with 1 billion of them are men. WHO data has stated that the number of smokers in the developing countries is 800 millions, i.e. $80 \%$ of smokers live in developing countries. ${ }^{1}$ Indonesia is the fifth country with the highest consumption of cigarettes and WHO data have showsed that 31.5 percent of Indonesian or 60 millions Indonesian are smokers. ${ }^{2}$ Data from 2004 National Survey have mentioned that 63.2 percents of 31.5 percents smokers in Indonesia are male. ${ }^{1}$

Ironically, people are familiar with the negative effects of tobacco in cigarettes and still the habit of smoking tends to increase either in the developed countries or developing countries, especially among young adults. In average, smoking may cause six deaths every minute. ${ }^{2}$

Talking about smoking habit, it has been proven as having close relationships with various diseases in various organs such as respiratory tract, lung and bladder cancers as well as cardiac diseases. In addition, smoking also relates to brain circulation disorders (known as stroke), eye 
cataract, and digestion diseases and may lead to early skin aging and even impotency. ${ }^{1}$ One of the effects of smoking towards oral cavity is the negative impact on the taste sensory organs with reduced taste sharpness that is apparent from increased taste threshold. ${ }^{3-5}$

Meanwhile, taste sensation is a sensation that is produced from food or other chemicals diluted in the mouth. ${ }^{6}$ For human, taste has a function to differentiate unwanted food, that may be deadly, from nutritious food. ${ }^{7}$ So he/she can choose his/her food according to his/her taste and specific nutrition needs for the body.

Regarding the taste sensation, the tongue has a very close relationship with taste specific sense because it has important organs that are involved in identifying food taste, i.e. taste receptors or taste buds. ${ }^{8,9}$ The taste receptors or taste buds are chemoreceptors. There are around 500-20,000 taste receptors ${ }^{10,11}$ distributed on the tongue papilla, epiglottis mucosa, and pharynx. ${ }^{12}$ These taste receptors give responses to the chemical used in this research, which is sucrosa. ${ }^{4}$ This chemical works on microvilli that are distributed in taste receptor pores to induce generator potentials that will create action potentials in sensory neurons. ${ }^{12}$ The apparent action potentials, in the form of taste impulses, are then transmitted along the afferent nerves to the taste center at the insular operculum in the cerebral cortex. In this site, the taste impulses will be perceived and identified as taste. ${ }^{10,13}$

Thus, the decreased taste function or sharpness among smokers are caused by the damaged sensory nerve ends of the taste organs or taste buds and the surrounding tissues. ${ }^{14}$ This decreased taste sense depends on the cigarette chemical content level, cigarette design and the period of smoking habit. ${ }^{15,16}$ Whereas the chemical contain of white cigarettes differs from clove cigarettes.

For illustration the cigarettes that are popular in Indonesia are white cigarette and clove cigarette. ${ }^{16}$ The two cigarettes are different in terms of the chemical contents and levels (nicotine and tar) as well as the cigarette design, i.e. the availability of filter. ${ }^{15,17}$ The higher level of nicotine and tar as well as the unavailable filter in the clove cigarette make the effect of smoking this cigarette towards the taste organs bigger than the white cigarette. ${ }^{17}$

Therefor, because of the problem stated above, this study is conducted to highlight those kinds of the difference, which is considered causing the decreased taste function.

\section{METHOD}

Population in this descriptive comparative study consists of young adult male students of Universitas Padjadjaran in Bandung and Jatinangor.

The sampling is performed using the purposive sampling method with population criteria as follow: Male in young adult age group (18-25 years old), White cigarette and clover cigarette smokers who smoke 5 to 10 cigarettes per day and have been smoking for a minimum of 3-5 years old.

Good subject systemic condition, not on medications, not wearing prosthetics or orthodontic appliance. The sample size is 60 persons that consist of 30 white cigarette smokers and 30 clover cigarette smokers.

The study procedure was performed as follows: Makingsucrosesolution withconcentrations of $0.0006 \mathrm{M} ; 0.001 \mathrm{M} ; 0.002 \mathrm{M} ; 0.004 \mathrm{M} ; 0.012$ M; $0.02 \mathrm{M} ; 0.028 \mathrm{M} ; 0.036 \mathrm{M} ; 0.044 \mathrm{M} ; 0.054 \mathrm{M}$; $0.06 \mathrm{M}$. The solution was made by diluting powder sucrose reagent with aquadest using a dilution formula of MiVi $=M f V f$. Based on the Murphy method, the perception threshold and taste identification threshold were tested in orderly manner to subjects who had been conditioned for not smoking and eat or drink within 1 hour before the measurement.

The subjects were then rinsing using the sucrose solutions starting from the lowest concentration to a concentration where the taste can be perceived and then continued until the taste was able to be identified accurately and correctly. In each period from one concentration to another concentration, a control solution (water) was given to neutralize the taste. The perception threshold value and taste identification threshold value were then recorded as the taste threshold value, The data was then analyzed using $t$ independent test and is presented in the form of average value and standard deviation with an error level (a) of 0,05. 
Table 1. Taste threshold between white and clove cigarette smokers

\begin{tabular}{cccc}
\hline Taste threshold & Smokers & Average & Deviation standard \\
\hline \multirow{2}{*}{ Perception threshold } & White cigarette smokers & 0,0119 & 0,0082 \\
& Clove cigarette smokers & 0,0151 & 0,0079 \\
& White cigarette smokers & 0,0292 & 0,0112 \\
\multirow{2}{*}{ Identification threshold } & Clove cigarette smokers & 0,0348 & 0,0097 \\
\hline
\end{tabular}

\section{RESULTS}

In Table 1, it is apparent that the perception threshold and identification threshold values for young adult male white smokers are $0.0119 \mathrm{M}$ with a standard deviation of 0.0082 and $0.0292 \mathrm{M}$ with a standard deviation of $0.0112 \mathrm{M}$, respectively. The perception threshold and identification threshold values in white cigarette smokers is the taste threshold value of individuals who smoke white cigarettes and meet the population criteria so that it is assumed that those individuals have experienced taste function disturbance due to white cigarette smoking because the normal threshold value for sweet sensation induced by sucrose in human is $0.01 \mathrm{M}^{7}$

In Table 1, it is also apparent that the perception threshold and identification threshold values for young adult male clove cigarette smokers are $0.0151 \mathrm{M}$ with a standard deviation 0.0079 and $0.0348 \mathrm{M}$ with a standard deviation of $0.0097 \mathrm{M}$, respectively. The perception threshold and identification threshold values in young adult male clove cigarette smokers is the taste threshold value of individuals who smoke clove cigarettes who meet the criteria of the population so that it is assumed that those smokers experience more severe taste function disorder than the white cigarette smokers. This is due to the level of chemical contents (nicotine and tar) in clove cigarette is higher than the white cigarette and also because there is no filter in clove cigarette to filter dangerous agents from the smoke such as nicotine, tar and carbon monoxide ${ }^{17}$ that leads to more taste bud damage in clove cigarette smokers. ${ }^{3,17}$ Therefore, the number of taste buds in clove cigarette smokers are fewer than those in the white cigarette smokers. The fewer number of taste buds is linearly compared with the decreased taste intensity in both types of smokers ${ }^{8}$ that the clove cigarette smokers need higher taste stimulus compared to the white cigarette smokers.

\section{DISCUSSION}

Besides the dangerous chemicals, the heat of the cigarette smoke can also irritate the oral mucosa because the mouth is the first organ to be affected and closer to the heat source. This heat irritation runs to the taste buds on the tongue and palate surface. In addition, the chronic irritation due to heat also causes changes in vascularization flow and saliva secretion that damage the pores and taste hairs. This condition reduces or diminishes the ability to sense the taste. $^{3}$

The results of this study is in line with the statements from Murphy ${ }^{4}$, Roth and Calmes and Christen ${ }^{3}$ who stated that smoking (both white cigarette and clove cigarette) may cause decreased taste sharpness that leads to increased taste threshold. Furthermore, these results also confirm Meursault ${ }^{17}$ statement that higher nicotine and $\operatorname{tar}$ content levels and the unavailability of filter in clove cigarettes cause higher risks for taste organs compared to the white cigarettes.

The risks brought by smoking white cigarette and clove cigarette smoking on the taste threshold have become a consideration in dental treatment and oral and dental health improvement because there are negative effects of smoking white cigarettes and clove cigarettes to the oral and dental tissues that the smokers are recommended to quit smoking. Dentists are expected to be able to help their patients to stop smoking to improve the general health degree and, specifically, oral and dental health.

\section{CONCLUSION}

There is no different in taste threshold (perception threshold) in young adult male white cigarette and clove cigarette smokers. There is a different of taste threshold (identification threshold) between the young adult male white 
cigarette smokers and clove cigarette smokers. The taste threshold (identification threshold) in young adult male clove cigarette smokers is higher compared to the taste threshold (identification threshold) of the young adult male white cigarette smokers.

\section{REFERENCES}

1. Aditama TY. Tuberkulosis, rokok, dan perempuan. Jakarta: Fakulty of medicine Universitas Indonesia; 2006.

2. Dewi D. Pengaruh kebiasaan merokok terhadap rongga mulut. J Dentika Universitas Sumatra Utara 2005;10(2):132-5.

3. Christen AG. The clinical effect of tobacco on oral tissue. JADA 1970;81:1078-82.

4. Murphy WM. The effect of complete dentures upon taste perception. J British Dent 1971;130:201-5.

5. Roth GI, Calmes R. Oral biology. Missouri: The CV Mosby Inc.; 1981.

6. Witherspoon JD. Physiology. New York: Harper \& Row, Publishers Inc.; 1984.

7. Guyton AC, Hall JE. Buku ajar fisiologi kedokteran. Jakarta: EGC; 1996.

8. Amerongen AVN. Ludah dan kelenjar ludah.
Yogyakarta: Universitas Gadjah Mada; 1991.

9. Pearce E. Anatomi dan fisiologi untuk paramedis. Jakarta: PT Gramedia Pustaka Utama; 1997.

10. Haroen ER. Analisis pengaruh astrigensia asam tanat obat kumur terhadap sensitivitas pengecapan melalui uji klinis metode Murphy. Majalah IImiah Kedokteran Gigi Universitas Trisakti IV-7; 2002. p. 161-4.

11. Linden RWA. Taste. J British Dent 1993;175(7):243-53.

12. Ganong WF. Buku ajar fisiologi kedokteran. Jakarta: EGC; 1999.

13. Essentials of oral physiology. St Louis: Mosby Inc.; 1995.

14. Mulyawati Y. Pengaruh rokok terhadap kesehatan rongga mulut. 2004 [cited 2007 Maret 17]. Available from: http: / /id wikipedia. org/wiki/alat kesehatan.com.

15. Ruslan G. Efek merokok terhadap rongga mulut. J PDGI 1993;42(2):22-5.

16. Sitepoe M. Kolesterol fobia dan keterkaitannya dengan penyakit jantung. Jakarta: P.T. Gramedia; 1992.

17. Meursault. Pembicaraan rokok. 2004 [cited 2007 Maret 17]. Available from: http:// id.wikipedia.org/wiki/pembicaraan rokok. 